\title{
DEVELOPMENT OF MELOXICAM ORAL LYOPHILISATES: ROLE OF THERMAL ANALYSIS AND COMPLEMENTARY TECHNIQUES
}

\author{
LUCIA MARIA RUS ${ }^{1 \#}$, SONIA IURIAN ${ }^{2 \#}$, IRINA KACSO $^{3}$, GHEORGHE BORODI $^{3}$, SEBASTIAN \\ PORAV ${ }^{3}$, SIMONA CODRUȚA HEGHES ${ }^{1}$, CRISTINA ADELA IUGA ${ }^{1,4 *}$, IOAN TOMUȚA ${ }^{2}$ \\ 1 "Iuliu Hațieganu” University of Medicine and Pharmacy Cluj-Napoca, Faculty of Pharmacy, Department of Drug Analysis, 6 \\ Louis Pasteur Street, 400349 Cluj-Napoca, Romania \\ 2 "Iuliu Hațieganu” University of Medicine and Pharmacy Cluj-Napoca, Faculty of Pharmacy, Department of Pharmaceutical \\ Technology and Biopharmaceutics, 41 Victor Babeș Street, 400012 Cluj-Napoca, Romania \\ ${ }^{3}$ National Institute of Research and Development for Isotopic and Molecular Technologies, 67-103 Donat Street, 400293 Cluj- \\ Napoca, Romania \\ 4 "Iuliu Hațieganu" University of Medicine and Pharmacy, Department of Proteomics and Metabolomics, MedFuture - Research \\ Centre for Advanced Medicine, 8 Victor Babeș Street, 400000 Cluj-Napoca, Romania
}

*corresponding author:iugac@umfcluj.ro

${ }^{\#}$ Authors with equal contribution

Manuscript received: September 2018

\begin{abstract}
The purpose of this study was to highlight the way in which thermoanalytical and complementary techniques can guide the development of meloxicam oral lyophilisates both in the preformulation and formulation stages, as well as for the final products characterization. Thermoanalytical methods (differential scanning calorimetry - DSC, thermogravimetry - TGA) and complementary methods (Fourier transform infrared - FTIR, X-Ray powder diffraction - XRPD, scanning electron microscopy - SEM) were applied in order to obtain a complete set of data. In the preformulation stage, the compatibility between meloxicam and excipients was assessed. DSC results showed the compatibility between meloxicam and excipients. Tg' measurement in the frozen state led to the addition of an annealing step at $-25^{\circ} \mathrm{C}$ into the freezing stage, to facilitate complete crystallization and end-product integrity. The designed lyophilization cycle yielded good cake appearance. The DSC, XRPD analysis as well as SEM morphology studies, performed in the final stage, evidenced that the meloxicam freezedried products were partially crystalline. By the TGA analysis the moisture content was evaluated in accordance or close to the recommended limits. In conclusion, thermoanalytical techniques are well suited for the design of freeze-drying process, in order to obtain good quality oral lyophilisates.
\end{abstract}

\section{Rezumat}

Scopul acestui studiu a fost acela de a evidenția felul în care tehnicile de analiză termică şi unele tehnici complementare pot ghida procesul de dezvoltare a liofilizatelor orale cu meloxicam, atât în etapele de preformulare și formulare, cât și pentru caracterizarea produselor finale. Metodele termice de analiză (analiza calorimetrică diferențială - DSC, analiza termogravimetrică - TGA) şi cele complementare (spectroscopia în infraroșu cu transformantă Fourier - FTIR, difracția de raze X XRPD, microscopia electronică de baleiaj - SEM) au fost aplicate pentru obținerea unui set complet de date. Astfel, în etapa de preformulare a fost studiată compatibilitatea dintre meloxicam și excipienții aleși. Rezultatele DSC au arătat existența compatibilității dintre aceștia. Determinarea Tg' în faza de înghețare a liofilizării a dus la includerea unui tratament termic la $-25^{\circ} \mathrm{C}$, cu scopul de a asigura structura cristalină și integritatea produsului final. Ciclul de liofilizare astfel optimizat a dus la obținerea unor liofilizate orale corespunzătoare vizual. Designul ciclului de liofilizare a fost realizat pornind de la datele DSC înregistrate, care au evidenţiat temperaturile critice asociate diferitelor caracteristici fizice ale materialelor în starea înghețată. Analizele DSC, XRPD precum și studiile de morfologie SEM efectuate în etapa finală, au evidențiat faptul că liofilizatele orale cu meloxicam obținute au fost parțial cristaline. Prin metoda TGA s-a determinat conținutul acestora în umiditate, rezultatele înregistrate fiind în concordanță sau aproape de limitele recomandate. În concluzie, tehnicile de analiză termică sunt foarte potrivite pentru designul procesului de liofilizare, în vederea obținerii unor liofilizate orale de calitate.

Keywords: freeze-drying, glass transition temperature, crystallinity, moisture content

\section{Introduction}

Oral lyophilisates are a category of orodispersible tablets (ODTs), prepared by freeze-drying of aqueous liquids/suspensions into porous units shaped like tablets, without application of any compaction force. Their preparation requires few non-toxic excipients (matrix forming agents and stabilizers), they are well accepted by patients for their light texture and fast disintegration after placement on the tongue, and offer improved biopharmaceutical properties compared to classic tablets $[1,4,11]$. 
On the other hand, lyophilization is an expensive process, running an optimized one being of great interest to pharmaceutical companies that produce freeze-dried products [21]. The lyophilisation process involves three steps, the freezing stage, in which the solution/suspension containing the active pharmaceutical ingredient (API) is cooled down below its specific solidification point, followed by the primary drying characterized by the sublimation of solvent under reduced pressure and finally, secondary drying that involves removal of water due to physical adsorption, chemical adsorption and water of crystallization by increasing the temperature [26, 44]. Optimizing a lyophilisation cycle presumes optimizing these three stages, in each one the formulation being characterized by different physical-thermal parameters [26]. In this respect, the most important information that can be obtained include the physical state of the materials in the frozen state (crystalline, amorphous, metastable, mixed), the critical temperatures associated with those different phases (glass transition temperature, eutectic melting temperature, collapse temperature) and the amount of moisture in the final product, in order to assure its long term stability. Differential scanning calorimetry (DSC) and thermogravimetry (TGA) are techniques well suited to evaluate these key parameters. DSC should be the first choice method to design and optimize a lyophilization cycle, due to its capability to provide a means of characterizing thermo physical properties which aid in the establishment of lyophilization process parameters [3, 17, 35, 44]. However, above all this, DSC is well known as a rapid screening technique for testing the physical-chemical interactions between components of a formulation, starting from the fact that the successful formulation of a stable and effective dosage form depends on careful selection of the excipients in the preformulation stage $[6,10,12,13,22,28,29,37,38$, $43,45,46]$. The DSC compatibility between the components of a pharmaceutical formulation is usually evaluated on the binary mixture of two components, the interaction being represented by a shift in the melting point, changes in the peak shape or area, the development of a new transition comparing to those observed in the initial thermograms, the increase or decrease in the number of peaks due to the mixture of components [12].

Moreover, TGA is a widely used method for determining the moisture content in drugs and drug [15] products as mass decrease versus temperature. Consequently, TGA is a well suited technique to predict the secondary drying cycle length in order to keep the freeze dried drug products in their stability moisture interval and also to permanently characterize the moisture content of the final drug products $[7,12]$.

Meloxicam (MEL) is a non-steroidal anti-inflammatory which acts as a selective inhibitor of cyclooxygenase-2 isoenzyme, which could be conditioned as an oral lyophilisate for several reasons. First of all the API is commonly used to treat inflammatory conditions in the elderly. They can often complain of dysphagia, which makes it difficult to administer classic tablets in the context of the poly-therapy specific to this category of patients [2]. Several studies found in the literature address ways to increase the solubility and dissolution rate of meloxicam, by developing solid dispersions [18, 33], drug-cyclodextrin inclusion complex [40] and nanosized particles $[23,40]$. Also, the inclusion of APIs in orodispersible tablets could lead to improved bioavailability $[2,19$, 20]. Meloxicam is a member of BCS II class, thus its absorption is limited by its dissolution rate. Therefore, its physical-chemical characteristics, therapeutic indications and the target patient population justify its use as oral lyophilisates. Since freeze-drying is a rather unpredictable process influenced by many variables, a reliable method to control it would be required.

The aim of this work was to demonstrate the utility of thermo-analytical techniques (DSC, TGA) in the development process of meloxicam oral lyophilisates, based on a scientific approach. DSC thermo-analytical technique was used in all of the development stages, starting with compatibility studies in the pre-formulation stage, followed by studies for the design of the freeze-drying process in the formulation stage and finally the end-product characterization. TGA method was applied in the final stage for moisture content determination. Fourier Transformed Infrared Spectroscopy (FTIR), X-Ray Powder Diffraction (XRPD) and Scanning Electron Microscopy (SEM) techniques were also used to, sustain and complete DSC results, as well as for the characterization of the prepared MEL oral lyophilisates in terms of crystallinity and morphology.

\section{Materials and Methods}

\section{Materials}

Meloxicam, MEL (Unichem Laboratoires Ltd., India) was used as the API (Active Pharmaceutical Ingredient), in micronized form; gelatin, GEL (JRS Pharma, Germany), sodium alginate, SA (BASF, Germany), croscarmellose sodium, CCS (FMC BioPolymer, Belgium) were chosen as matrix forming agents and polyvinylpyrollidone K30, PVP (BASF, Germany), polyethylene glycol 4000, PEG (Merck, Germany), poloxamer 188, POLOX (BASF, Germany) were used as suspension stabilizers.

Methods

Lyophilization. The experimental formulations were prepared according to Table I and used to assess the effects of various components and process parameters on their physico-chemical characteristics. The qualitative factors were the type of stabilizing agent (PVP, POLOX or PEG) and the type of matrix forming agent 
FARMACIA, 2019, Vol. 67, 1

(GEL, CCS, SA). The quantitative factors varied on three levels, established according to each of the substances' characteristics, resulting in ten formulations (Table I). $50 \mathrm{~mL}$ suspension of each of the 10 formulations was prepared. Briefly, the corresponding amounts of the stabilizing agent and matrix forming polymer were dissolved in distilled water. Further, meloxicam was suspended in the previous solution to a content of $7.5 \mathrm{mg} / \mathrm{mL}$.

Table I

Experimental formulations

\begin{tabular}{ccccc}
\hline $\begin{array}{c}\text { Suspension/Oral } \\
\text { lyophilisate }\end{array}$ & $\begin{array}{c}\text { Type of stabilizing } \\
\text { agent }\end{array}$ & $\begin{array}{c}\text { Stabilizing agent } \\
\text { ratio }(\mathbf{\%}, \mathbf{w} / \mathbf{V})\end{array}$ & $\begin{array}{c}\text { Matrix forming } \\
\text { agent }\end{array}$ & $\begin{array}{c}\text { Matrix forming agent } \\
\text { ratio (\%, w/V) }\end{array}$ \\
\hline F1/MEL1 & PVP & 0.25 & GEL & 2.50 \\
F2/MEL2 & PVP & 1.00 & CCS & 4.00 \\
F3/MEL3 & PVP & 1.75 & SA & 3.00 \\
F4/MEL4 & POLOX & 0.25 & CCS & 6.00 \\
F5/MEL5 & POLOX & 1.00 & SA & 1.00 \\
F6/MEL6 & POLOX & 1.75 & GEL & 5.00 \\
F7/MEL7 & PEG & 0.25 & SA & 2.00 \\
F8/MEL8 & PEG & 1.00 & GEL & 7.50 \\
F9/MEL9 & PEG & 1.75 & CCS & 2.00 \\
F10/MEL10 & PVP & 0.25 & GEL & 5.00 \\
\hline
\end{tabular}

F1 - F10, suspension formulations; MEL 1 - MEL10, meloxicam oral lyophilisates; PVP, polyvinylpyrollidone K30; POLOX, poloxamer 188; PEG, polyethylene glycol 4000; GEL, gelatin; CCS, Sodium Croscarmellose; SA, sodium alginate.

The resulting suspensions were submitted to freezedrying (VirTis Advantage Plus, SP Scientific, Gardiner, USA). $0.5 \mathrm{~mL}$ of suspension was poured into blister sockets (blister material: PVC-Aclar ${ }^{\circledR}$ PCTFE, polychloro-tri-fluoro-ethylene, cavity sizes $12.70 \mathrm{~mm}$ diameter x $5.50 \mathrm{~mm}$ depth) and then freeze-dried following a cycle that included freezing down to $-50^{\circ} \mathrm{C}$. The annealing step consisted of warming the samples at $-25^{\circ} \mathrm{C}$ for 2 hours, followed by cooling at $-50^{\circ} \mathrm{C}$. Primary drying was performed at $-25^{\circ} \mathrm{C}$ and $0.2 \mathrm{mbar}$ for 20 hours and secondary drying at $10^{\circ} \mathrm{C}$ and 0.2 mbar for 6 hours. The suspension formulations coded F1 - F10 led to oral lyophilisates MEL1 MEL10.

Differential Scanning Calorimetry (DSC) studies For pre-formulation studies, $500 \mathrm{mg}$ of physical binary mixtures of MEL with each excipient alone were prepared in the $1: 1(\mathrm{w} / \mathrm{w})$ ratio by grinding the components in an agate mortar for approximately 5 minutes. The 1:1 (w/w) ratio was chosen to maximize the probability of observing any interactions.

Samples of approximately $3 \mathrm{mg}$ pure meloxicam, individual excipients and their 1:1 (w/w) physical mixtures were weighed in $40 \mu \mathrm{L}$ hermetically sealed and pierced aluminium pans and scanned in the DSC 822 equipment (Mettler Toledo, Columbus, Ohio, United States) under a dynamic nitrogen atmosphere $(50 \mathrm{~mL} / \mathrm{min})$ and a heating rate of $10^{\circ} \mathrm{C} / \mathrm{min}$, in a temperature range of $25-400^{\circ} \mathrm{C}$. An empty $40 \mu \mathrm{L}$ hermetically sealed and pierced aluminium pan was used as a reference. The DSC cell was calibrated with indium (m.p. $=156.6^{\circ} \mathrm{C} ; \Delta$ Hmelting $=28.54 \mathrm{~J} / \mathrm{g}$ ) and zinc (m.p. $\left.=419.6^{\circ} \mathrm{C}\right)$.

In order to design the freeze-drying cycle, samples of approximately $25 \mathrm{mg}$ MEL suspensions (Table I, F1 F10) were analysed for Tg' determination using the same method conditions as in the pre-formulation stage but in two temperature steps, the first one between $25^{\circ} \mathrm{C}$ and $-55^{\circ} \mathrm{C}$ with a cooling rate of $10^{\circ} \mathrm{C} / \mathrm{min}$ and the second one between $-55^{\circ} \mathrm{C}$ and $25^{\circ} \mathrm{C}$ with a heating rate of $20^{\circ} \mathrm{C} / \mathrm{min}$.

Finally, the DSC method used for MEL oral lyophilisates (MEL 1- MEL 10) analysis was the one applied in the pre-formulation stage.

In all cases the resulting DSC thermograms were analysed using STAR ${ }^{\circledR} \mathrm{SW} 12.10$ software.

Fourier Transform Infrared Spectroscopy (FTIR)

The FTIR spectra of the pure drug, individual excipients and drug excipient mixtures were recorded in the pre-formulation stage on a FT IR-6100 (Jasco, Germany) spectrometer, using $\mathrm{KBr}$ discs, at scanning range from $400-4000 \mathrm{~cm}^{-1}$ and resolution of $4 \mathrm{~cm}^{-1}$. $X$-ray Powder Diffraction (XRPD)

The XRPD method was applied in the pre-formulation stage for drug/excipient compatibility screening as well as in the final stage for meloxicam oral lyophilisates characterization. The XRPD data was obtained with a Bruker D8 Advance diffractometer in the BraggBrentano geometry. The diffractometer is equipped with a Ge (111) monochromator in the incident beam in order to remove $\mathrm{CuK} \beta$ and $\mathrm{CuK} \alpha 2$ radiation for obtaining a monochromatic beam corresponding to $\mathrm{CuK} \alpha 1$ radiation with wavelength $\lambda=1.54056 \AA$. The XRPD patterns were recorded with a super-speed LynxEye position detector in the range of $5-50^{\circ}(2 \theta)$. Thermogravimetric analysis (TGA)

The moisture content of MEL freeze-dried products was estimated as a percentage using TGA/SDTA821e (Mettler Toledo, Columbus, Ohio, United States) system in the temperature range of $25-300^{\circ} \mathrm{C}$, under a dynamic atmosphere of nitrogen $(50 \mathrm{~mL} / \mathrm{min})$ and a heating rate of $10^{\circ} \mathrm{C} / \mathrm{min}$, using alumina $70 \mu \mathrm{L}$ crucibles and samples of approximately $4 \mathrm{mg}$. TGA 
FARMACIA, 2019, Vol. 67, 1

thermograms were analysed using $\mathrm{STAR}^{\circledR} \mathrm{SW} 12.10$ software.

\section{Scanning Electron Microscopy (SEM)}

SEM was used to assess the morphology of the freezedried process. Samples were extracted from blister sockets and deposited on a $2 \mathrm{~cm}$ Leit tab over an aluminium stub, followed by a $10 \mathrm{~nm}$ gold coating to reduce the charging of the samples. Coating was done with a Quorum Sputter Coater Q150T ES. SEM analysis was done at $30 \mathrm{kV}$ using a Hitachi SU8230 High Resolution microscope equipped with a cold field emission gun.

\section{Results and Discussion}

\section{Excipients selection}

The critical quality attributes of OLs include their disintegration, dissolution and mechanical properties, therefore the excipients were chosen for their previously reported ability to improve the quality profile.

As matrix forming agents we chose GEL, as the first used matrix forming agent in the Zydis ${ }^{\circledR}$ dosage form, following viscosity studies (results not included into the manuscript) that led to the quantitative variation levels of 2.5 - $5-7.5 \%$. CCS, usually used as a super-disintegrant in oral solid dosage forms, is known for its high hydrating and swelling capacity that grants suspension stability before freezing and even enhances API dissolution [24]. SA was reported

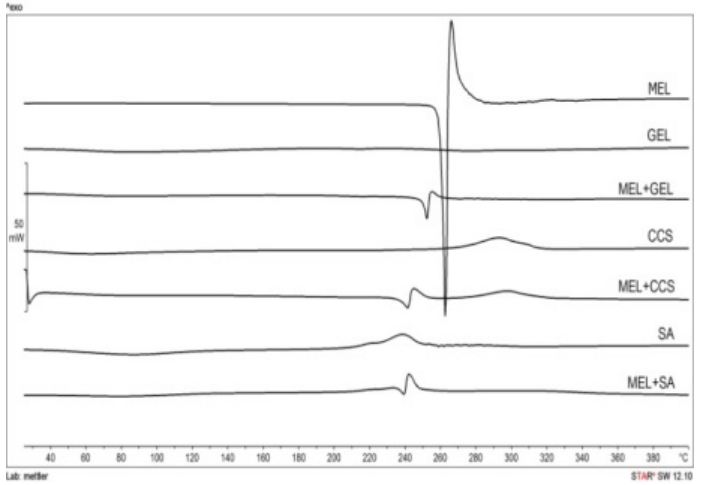

(a) for its ability to yield high viscosity dispersions at low concentrations [47]. The concentration levels were chosen from previous viscosity studies (results not shown) so that the dispersions would be fluid enough to be poured into blister sockets and viscous enough to prevent settling phenomena: 2 - 4 - $6 \%$ for CCS and 1 - 2 - 3\% for SA [19].

As stabilizers, we chose two polymers (PVP and PEG) and a non-ionic surfactant (POLOX). PVP was previously used as an agglomeration inhibitor [9, 34] with good results regarding the dissolution rate [23]. POLOX was confirmed as one of the most efficient stabilizers that inhibited the crystal aggregation capacity [48]. Its high solubilizing capacity was reported by Mata et al. [25]. Guided by literature reported results, their weight concentrations in volume were varied on three levels: $0.25-1-1.75 \%(w / V)$ [19].

Pre-formulation study

In the pre-formulation stage of product development, the DSC method was used to assess the compatibility of MEL with selected excipients. The FT-IR spectroscopy and X-ray powder diffraction techniques were applied to complete the DSC compatibility results.

First, the DSC method was chosen to evaluate the behaviour of MEL in the presence of selected excipients. The thermograms of pure API, individual excipients as well as physical mixtures with excipients of MEL 1:1 (w/w) are presented in Figures 1(a) and 1(b).

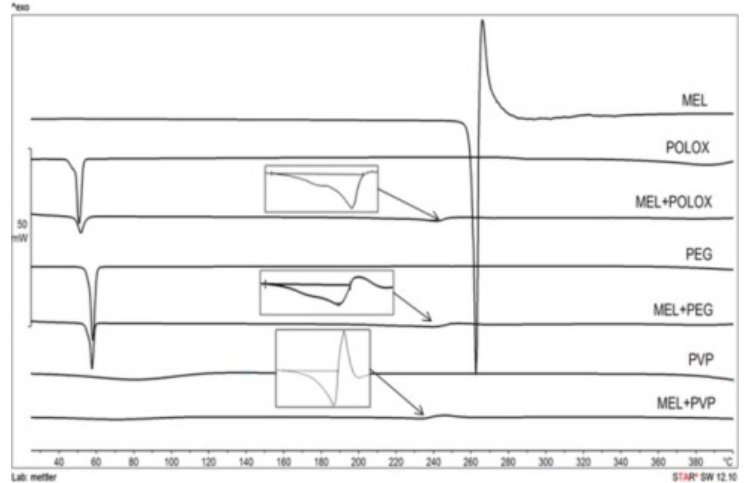

(b)

Figure 1.

DSC thermogram of: (a) MEL, GEL, MEL + GEL, CCS, MEL + CCS, SA, MEL + SA; (b) MEL, POLOX, MEL + POLOX, PEG, MEL + PEG, PVP, MEL + PVP

MEL, meloxicam; GEL, gelatin; CCS, Sodium Croscarmellose; SA, sodium alginate; POLOX, poloxamer 188; PEG, polyethylene glycol 4000; PVP, polyvinylpyrollidone K30

The DSC thermogram of pure MEL (Figures 1(a) and $1(\mathrm{~b}))$ showed a first sharp melting endothermic event at $262.89^{\circ} \mathrm{C}$ with Tonset $=261.46^{\circ} \mathrm{C}$ and $\Delta$ Hmelting $=147.90 \mathrm{~J} / \mathrm{g}$. The decomposition of MEL starts concurrently with its melting. The meloxicam DSC data are consistent with those previously reported in the literature $[2,12,50]$.

The individual evaluations of matrix forming agents were in agreement with previously reported thermal behaviour, as it follows: GEL displayed a large broad endotherm corresponding to moisture release at $87.44^{\circ} \mathrm{C}$, a relatively large endothermic transition at $214.8^{\circ} \mathrm{C}$ and decomposition, compared to the results that Mukherjee et al. reported, moisture loss at $90.3^{\circ} \mathrm{C}$, followed by decomposition above $200^{\circ} \mathrm{C}$ [30]. CCS showed moisture release also reported by Sarfraz et al. [39], followed by melting and decomposition. SA presented moisture loss at $87^{\circ} \mathrm{C}$ and decomposition at $240^{\circ} \mathrm{C}$, as Soares et al. have previously obtained [42]. 
FARMACIA, 2019, Vol. 67, 1

Concerning the thermal behaviour of the stabilizing agents, our DSC obtained data are in agreement with the literature ones that indicate melting peak at $58.9^{\circ} \mathrm{C}$ for PEG $4000[27,36]$, melting endotherm at $54.66^{\circ} \mathrm{C}$ for POLOX $[36,49]$ respectively a large dehydration band in the $50^{\circ} \mathrm{C}-100^{\circ} \mathrm{C}$ temperature range [32] and a softing endotherm at $150^{\circ} \mathrm{C}$ for PVP [36]. Analysing the DSC thermograms of the MEL/excipients 1:1 (w/w) physical mixtures (Figures 1(a) and 1(b)), potential incompatibilities could be identified when mixing the API with all the excipients taken into study.

In the DSC thermograms of MEL 1:1 (w/w) physical mixtures with the matrix forming agents (GEL, CCS, SA) (Figure 1(a)) the melting endotherm of pure drug was well preserved but shifted to lower temperatures compared to the one in the single API thermogram (Table II). That could be interpreted as potential incompatibility; however, it could be due to mixing with the excipients that lowers the purity of each component in the mixture [46]. In the situation of physical mixtures of MEL:GEL and MEL:CCS, DSC compatibility was previously reported [2].

In the thermograms of MEL 1:1 (w/w) physical mixtures with the stabilizing agents (PEG, POLOX, PVP) (Figure 1(b)) the drug melting event could be identified but it is very large and shifted to lower temperatures (Table II). The reason for significant shifting of drug peak at lower temperature could be again because of mixing with the excipients which lowers the purity of each component in the mixture. Also, the fact that the melting peaks for all excipients appeared in the mixture thermograms at Tonset $=55.51^{\circ} \mathrm{C}$ for PEG, Tonset $=48.32^{\circ} \mathrm{C}$ for $\mathrm{POLOX}$ and Tonset $=160.66^{\circ} \mathrm{C}$ for PVP respectively, before the melting endotherm of MEL, indicates that the drug could be partially solubilized in the melting excipients with the consequences described above [31]. Concerning the MEL:PEG physical mixture, their compatibility was previously DSC proven by Abd Elbary [2]. For physical mixture of MEL:PVP reported data sustain our DSC results and proved drug preservation in the mixture by HPLC, therefore the incompatibility was not confirmed [12].

The thermoanalytical data of MEL and physical mixtures 1:1 (w/w) with excipients are presented in Table II. Following the DSC compatibility studies between MEL and chosen matrix forming agents (GEL, CCS, SA) respectively stabilizing agents (PEG, POLOX, PVP), we could conclude that possible interaction appears between the components of the binary drug/ excipient mixtures.

Therefore, the FTIR and XRPD methods were used in this stage to avoid misinterpretation of the DSC compatibility data and to complete them.

Table II

Thermoanalytical DSC data of MEL and MEL in drug/excipient 1:1 (w/w) physical mixtures

\begin{tabular}{cccc}
\hline Sample & Tonset $\left({ }^{\circ} \mathbf{C}\right)$ & Tpeak $\left({ }^{\circ} \mathbf{C}\right)$ & $\Delta$ Hmelting $(\mathbf{J} / \mathbf{g})$ \\
\hline MEL & 261.46 & 262.89 & 147.90 \\
MEL + GEL & 249.40 & 251.70 & 63.67 \\
MEL + CCS & 236.38 & 241.07 & 45.94 \\
MEL + SA & 236.10 & 239.34 & 18.01 \\
MEL + POLOX & 223.95 & 241.37 & 61.05 \\
MEL + PEG & 215.64 & 239.58 & 59.05 \\
MEL + PVP & 213.38 & 232.97 & 27.24 \\
\hline
\end{tabular}

MEL, meloxicam; GEL, gelatin; CCS, Sodium Croscarmellose; SA, sodium alginate; POLOX, poloxamer 188; PEG, polyethylene glycol 4000; PVP, polyvinylpyrollidone K30

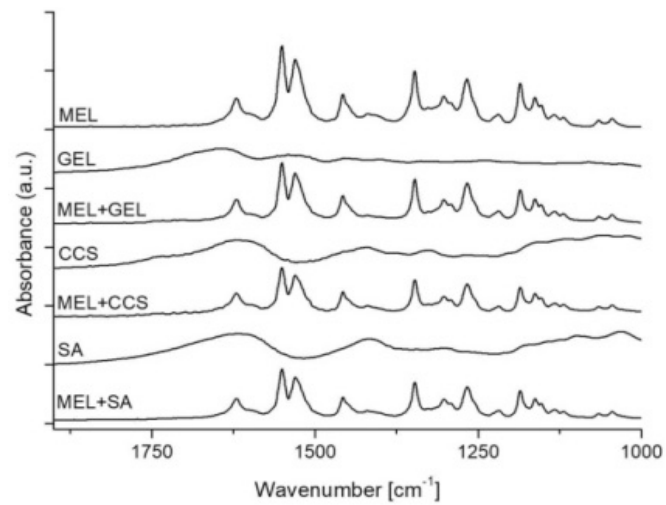

(a)

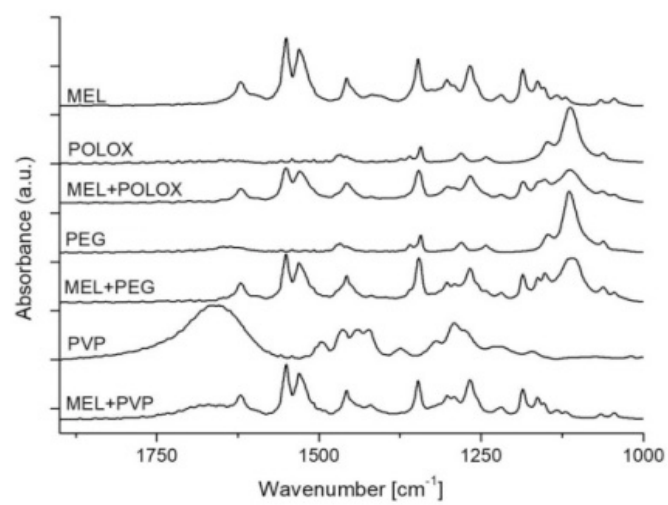

(b)

Figure 2.

FTIR spectra of: (a) MEL, GEL, MEL + GEL, CCS, MEL + CCS, SA, MEL + SA; (b) MEL, POLOX, MEL + POLOX, PEG, MEL + PEG, PVP, MEL + PVP

MEL, meloxicam; GEL, gelatin; CCS, Sodium Croscarmellose; SA, sodium alginate; POLOX, poloxamer 188; PEG, polyethylene glycol 4000; PVP, polyvinylpyrollidone K30 
FTIR spectra of MEL, excipients and MEL physical mixtures with formulation excipients were recorded. In Figures 2(a) and 2(b) the domain $1000-1900 \mathrm{~cm}^{-1}$ is shown, containing the peaks of the most important functional groups.

FTIR spectra of pure MEL presented sharp absorption bands at $3289 \mathrm{~cm}^{-1}(-\mathrm{NH})$ stretching, at $2968 \mathrm{~cm}^{-1}$ for $(\mathrm{C}-\mathrm{H})$ stretching, aromatic, at $2920 \mathrm{~cm}^{-1}$ for $(\mathrm{C}-\mathrm{H})$ stretching, aliphatic $\mathrm{CH} 3 \mathrm{sym}$, at $1620 \mathrm{~cm}^{-1}$ for $(\mathrm{C}=\mathrm{O})$ stretching of the amide, at $1530 \mathrm{~cm}^{-1}$ for $(\mathrm{C}=\mathrm{N})$ stretching, at $1457 \mathrm{~cm}^{-1}$ for $(\mathrm{C}=\mathrm{C})$ stretching of the aromatic ring, at $1347 \mathrm{~cm}^{-1}$ for and $1153 \mathrm{~cm}^{-1}$ for two sulphonyl groups ( $\mathrm{S}=\mathrm{O}$ stretching vibration), in accordance with previously recorded data $[2,18,33$, 50]. These frequencies are not shifted in binary MEL excipients 1:1 (w/w) mixtures. FTIR spectra showed

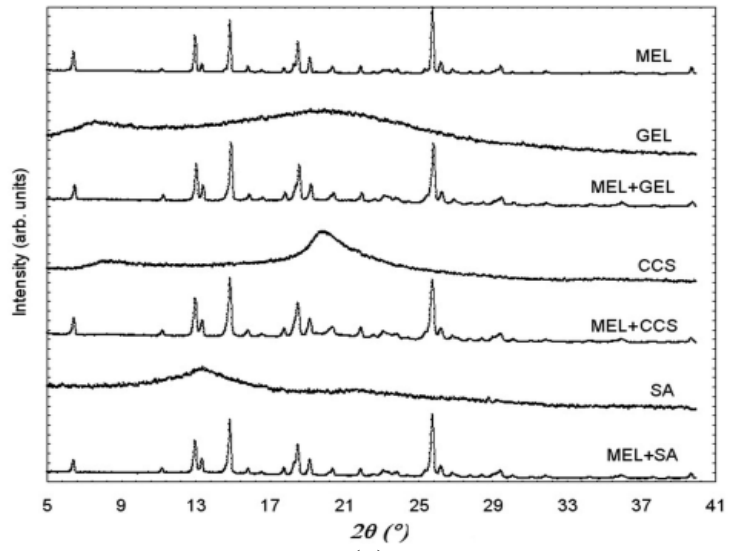

(a) that the characteristics bands of MEL were not altered in binary mixtures indicating no interactions between the drug substance and selected excipients.

The XRPD pattern $\left(2 \theta\right.$ domain $\left.=5^{\circ}-40^{\circ}\right)$ of MEL, excipients and MEL/excipients 1:1 (w/w) physical mixtures are shown in Figures 3(a) and 3(b). The presence of numerous distinct peaks in the XRPD spectra indicates that the studied API is a crystalline material. The $2 \theta$ values of the more intensive peaks for MEL are 13.10, 14.94, 17.90, 18.44, 18.62, 19.26, $22,25.5,25.8$ and 26.38 which confirm the previously recorded data $[14,20,23,40]$. The XRPD patterns of the physical mixtures of MEL with excipients did not show any new peaks or absence of any parent peaks (Figures 3(a) and 3(b)), thus revealing the compatibility of meloxicam with all selected excipients.

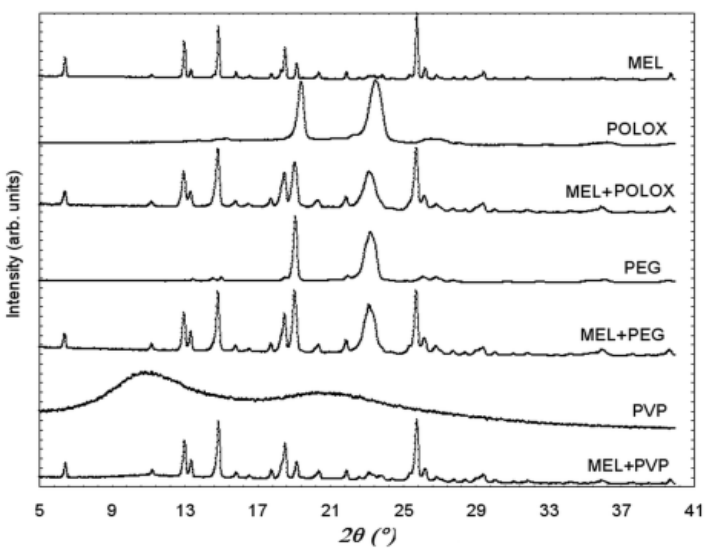

(b)

Figure 3.

XRPD pattern of: (a) MEL, GEL, MEL + GEL, CCS, MEL + CCS, SA, MEL + SA; (b) MEL, POLOX, MEL + POLOX, PEG, MEL + PEG, PVP, MEL + PVP

MEL, meloxicam; GEL, gelatin; CCS, Sodium Croscarmellose; SA, sodium alginate; POLOX, poloxamer 188; PEG, polyethylene glycol 4000; PVP, polyvinylpyrollidone K30

The FTIR as well as the XRPD analysis confirmed the results obtained using DSC, indicating no interactions between MEL and selected excipients.

Thus, following DSC, FTIR and XRPD studies in the first stage of the study, the matrix forming agents (gelatin, sodium alginate and croscarmellose sodium) as well as the suspension stabilizers (polyvinylpyrollidone K30, polyethylene glycol 4000, poloxamer 188) were found to be compatible with meloxicam. No physical or chemical interaction between drugs and excipients was detected. The compatibility of meloxicam with excipients is a topic widely discussed in the literature, regarding the preparation of classic pharmaceutical dosage form tablets [12], but also transdermal patches [50] or orally disintegrating tablets produced by direct compression [14, 41]. Our preformulation study confirmed the results previously discussed by Abd Elbary et al. [2] concerning the compatibility of meloxicam with freeze drying excipients meant for orodispersible dosage forms preparation. In addition to the excipients evaluated by Abd Elbary et al., our research also included sodium alginate and poloxamer 188. The XRPD and FTIR compatibility conducted studies have highlighted the stability of meloxicam in the presence of the excipients mentioned above. Based on the experimental data obtained in the pre-formulation stage, the excipients for the meloxicam freeze dried tablets were chosen.

DSC studies for the design of the lyophilisation process It is known that the freeze-drying process relies on the vapour transfer from a high-pressure area on the shelf to a lower pressure at the surface of the condenser, resulting in a very porous, low density cake containing the stabilized drug. Since the sublimation rate (drying rate) is temperature dependent, use of the highest possible temperature during primary drying provides maximum drying efficiency at lowest process cost. Thus, in order to select the optimum drying temperature, it is necessary to understand the physical characteristics of the components used in the formulation that is to be freeze-dried and the critical temperatures associated with these characteristics. 
FARMACIA, 2019, Vol. 67, 1

To this effect, the ten prepared formulations (Table I) containing meloxicam and excipients compatible with the drug substance selected after the first step were subjected to a freezing/warming up program, as presented in the Material and Methods section, in order to identify the presence of any type of thermal critical event (glass transition temperature) during the warming step, as well as for developing an annealing protocol to convert the metastable glassy phase of the samples (if existing) to the more crystalline and stable form. As shown by Ayensu et al. [7], during annealing small ice crystals merge into larger ones, which results in a freeze-dried product with larger pores and the sublimation rate increases in primary drying stage.

In this stage of product development, DSC was used to examine if the MEL suspensions prepared for lyophilization are crystalline/amorphous or partially amorphous freeze concentrated systems, the last two being identified by the presence of the glass transition (Tg'). The Tg' is also called 'the maximally freeze - concentrated system temperature" where the viscosity attains high values that do not allow anymore ice forming $[17,44]$. Tg' appears in the warming part of a DSC thermogram as a change in the heat capacity reflected by an "S" change in the baseline when previously cooling the aqueous formulations; the solute does not completely crystallize. It is well known that during the primary drying and ice sublimation, the samples must be kept at least 2 $5^{\circ} \mathrm{C}$ below $\mathrm{Tg}$ ' so that the products are stabilized in amorphous glass and protected from collapse. If the products temperature is allowed to rise above $\mathrm{Tg}$ ' then some of the ice will melt back into the non-ice phase resulting in their collapse, meaning obtaining an inelegant and unacceptable pharmaceutical form but also an unstable one $[3,16,26]$. As stated in literature $[7,8,26,44]$. DSC is the most common thermal technique used to measure the glass transition and thus to design an optimal primary drying lyophilization step. The presence of Tg' was detected in the DSC thermograms of meloxicam formulations 3, 4, 8 . Moreover, formulation F8 displayed a recrystallization phenomenon which could be attributed to the association of MEL with PEG [19] in the frozen state. The recorded Tg' values are presented in Figure 4.

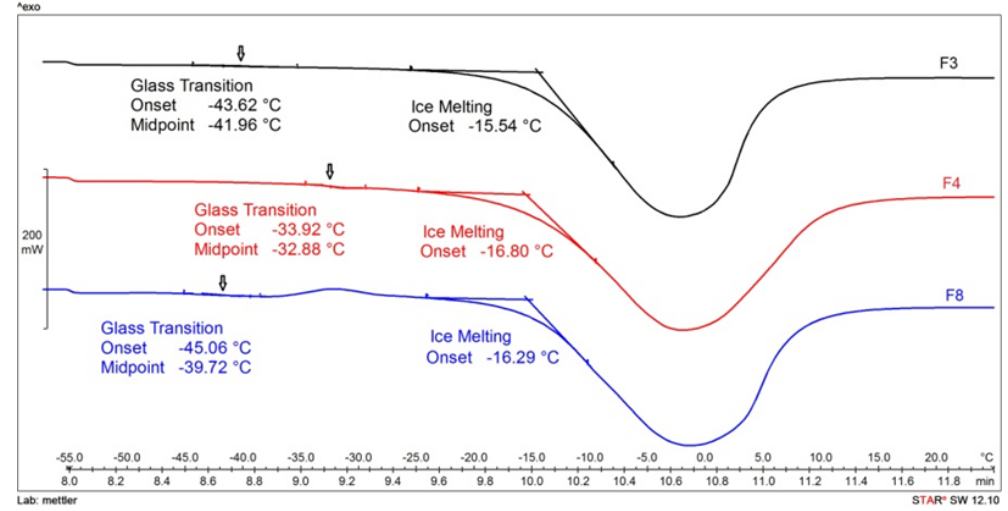

Figure 4.

DSC thermograms of meloxicam formulations presenting glass transition (Tg') F3, F4, F8, meloxicam suspension formulations $3,4,8$

The temperature of $-25^{\circ} \mathrm{C}$ was chosen as annealing temperature since it was above the detected Tg' and the endpoint of recrystallization and below the eutectic/ ice melt endotherm transition that begins for each formulation at approximately Tonset $=-17^{\circ} \mathrm{C}$ (Figure 4). As a result, not only the three formulations presenting $\mathrm{Tg}$, , but all the ten formulations were subjected by DSC to an annealing hold step at $-25^{\circ} \mathrm{C}$ for ten minutes. The performed annealing operation allowed the glass to relax and crystallize during the freezing step. After the annealing treatment the glass transition thermal event disappeared in the heating cycle for formulations 3, 4 and 8, proving that the process was successful and an indication of obtaining products with more desirable physical characteristics. Based on the thermal events observed during the heating cycle, an annealing temperature of $-25^{\circ} \mathrm{C}$ was integrated into the freezing stage of the lyophilisation cycle.

The final freeze-drying process consisted of a freezing stage down to $-50^{\circ} \mathrm{C}$ set upon the equipment capabilities, followed by an annealing step at $-25^{\circ} \mathrm{C}$ for 2 hours and primary drying at $-25^{\circ} \mathrm{C}$ as resulted from DSC studies. Secondary drying was performed at $10^{\circ} \mathrm{C}$ and 0.2 mbar for 6 hours in order to remove residual moisture.

\section{Oral dosage form characterization}

The end-products, meloxicam oral lyophilisates, were evaluated by thermal analysis (DSC, TGA). Thus DSC was applied to determine their crystallinity and the TGA measurements for the moisture content. The crystallinity DSC results were completed by XRPD data, as shown in Figures 6(a) and 6(b). The morphology of oral lyophilisates was also analysed, using SEM method. 
Crystallinity studies

While X-ray powder diffraction is commonly used to detect the presence and extent of crystallinity in solid dispersions for its high specificity, DSC has also been frequently used for this purpose. Often, both techniques are used together to provide a more comprehensive evaluation of sample crystallinity. Several studies have used DSC qualitatively, either to evaluate if crystallization occurs during heating, or if a melting endotherm, indicative of crystalline material arising from processing or storage, is present [8].

The ten MEL oral lyophilisates were scanned by DSC in the temperature domain $25-400^{\circ} \mathrm{C}$. Their crystallinity was appreciated from the area of the meloxicam melting peak $(\mathrm{J} / \mathrm{g})$. The measured MEL melting area for each of the lyophilisates was compared to the value for the $100 \%$ crystalline meloxicam. The crystallinity of pure MEL was calculated from the structural data of the crystallites that have been previously determined using X-ray diffraction. The area value of the $100 \%$ crystalline meloxicam used was $147.90(\mathrm{~J} / \mathrm{g})$, and it was obtained analysing in DSC a mass of $1.3 \mathrm{mg}$ meloxicam. It was taken into account that, according to Araújo et al. [5] the melting heat undergoes small variations when the sample mass is changed. Thus, the meloxicam melting peak was clearly visible in the DSC thermogram of oral lyophilisates MEL1, MEL6, MEL8, MEL10 (Figure 5) which contain gelatin as a matrix forming agent with some slight changes in terms of the melting peak value due to the mixing with the excipients. Its small area $(13.04(\mathrm{~J} / \mathrm{g})$ for MEL1; $0.74(\mathrm{~J} / \mathrm{g})$ for MEL6; $0.64(\mathrm{~J} / \mathrm{g})$ for MEL8; $3.15(\mathrm{~J} / \mathrm{g})$ for MEL10) indicates that the degree of crystallinity is low comparing to the value for the $100 \%$ crystalline meloxicam, $147.90(\mathrm{~J} / \mathrm{g})$.

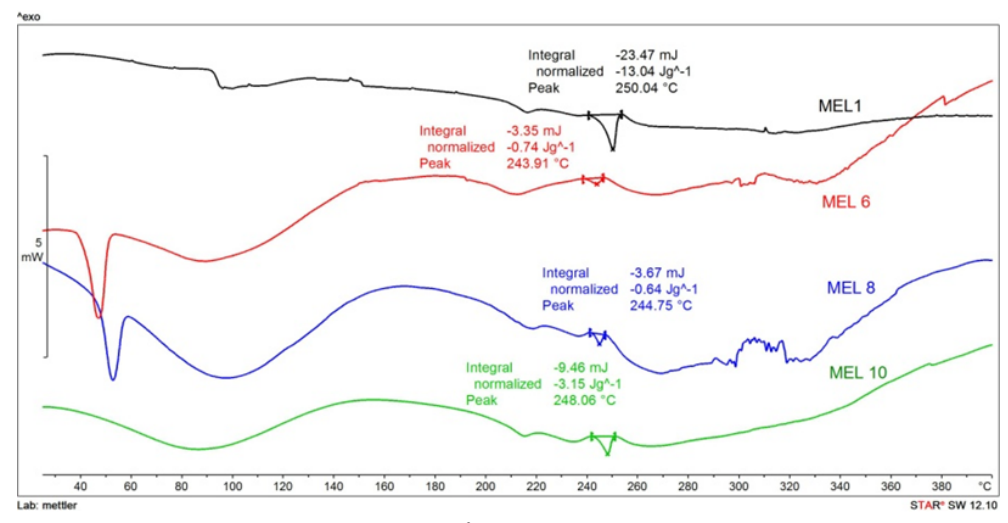

Figure 5.

DSC thermograms of meloxicam oral lyophilisates containing gelatin as matrix forming agent MEL1, MEL6, MEL8, MEL10, meloxicam oral lyophilisates 1, 6, 8, 10

In the situation of oral lyophilisates MEL2, MEL4, MEL9, containing sodium croscarmellose, the meloxicam melting event area cannot be correctly integrated because of the partial superposition with the excipient decomposition thermal event. However, the fact that it appears much wider compared to the melting peak of the $100 \%$ crystalline meloxicam indicates the amorphisation of the API in the previously mentioned meloxicam oral lyophilisates. For meloxicam oral lyophilisates MEL3, MEL5, MEL7 containing sodium alginate as a matrix forming agent the meloxicam melting peak cannot be seen due to the total overlapping of the decomposition thermal event of the excipient.

Further, the $\mathrm{X}$ ray diffraction technique has been used to complete the crystallinity characterization of the meloxicam formulations offered by DSC [44]. The XRPD patterns of the meloxicam oral lyophilisates are shown in Figures 6(a) and 4(b). The decrease in crystallinity of the final lyophilized MEL products comparing to the $100 \%$ crystalline API can be easily seen in the XRPD patterns as the decrease in the intensity of the more characteristic peaks for MEL as well as their widening. This can be explained by the fact that the original crystalline MEL was physically modified after mixing with the formulation excipients [19]. The existence of the amorphous structures in the MEL oral lyophilisates could give the API formulated in this way a higher dissolution rate thus a possible better bioavailability, while the existence of the crystalline ones could confer the stability during storage [7]. 


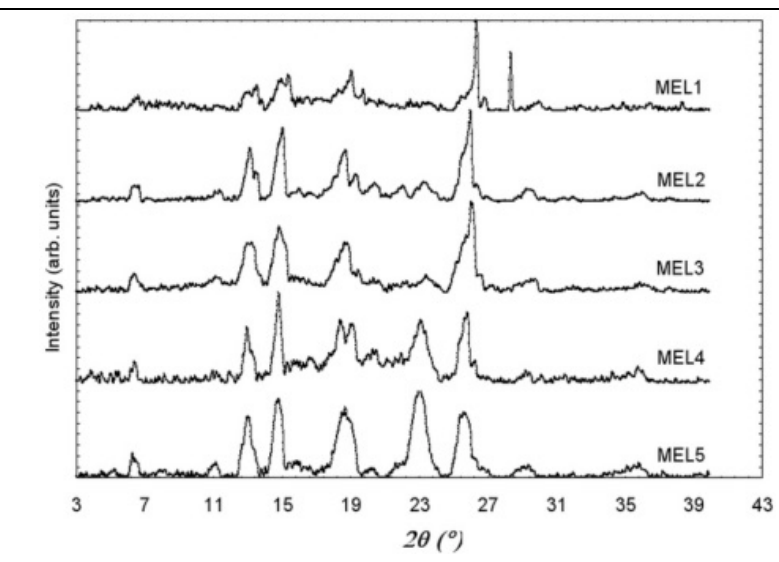

(a)

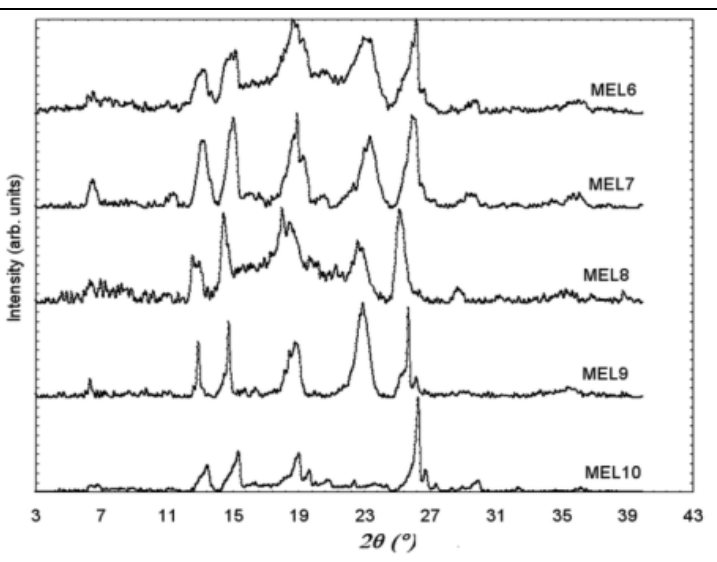

(b)

Figure 6.

XRPD patterns of meloxicam oral lyophilisates: (a) MEL1 - MEL5; (b) MEL6 - MEL10 MEL1 - MEL10, meloxicam oral lyophilisates 1-10

\section{Moisture content}

The TGA method was used for MEL oral lyophilisates moisture content determination, considering that it is important to know this parameter for a freezedried pharmaceutical product in order to assure its long-term stability. After the primary drying stage of the lyophilisation process, during which free ice is sublimed, no melt-back could be seen for none of the 10 formulations, so it can be concluded that during this stage all the adsorbed surface water was removed. In addition to that, there remains a quantity of moisture bound to the products that is harder to remove. It is important to determine this quantity of moisture to be able to establish the secondary drying duration to ensure fully dried drug moisture content generally established between $\leq 1 \%$ and $3 \%$ [7].

Table III

Meloxicam oral lyophilisates parameters

\begin{tabular}{cc}
\hline MEL oral lyophilisate & Moisture content \% (TGA) \\
\hline MEL1 & 6.66 \\
MEL2 & 5.92 \\
MEL3 & 4.04 \\
MEL4 & 4.71 \\
MEL5 & 0.45 \\
MEL6 & 3.12 \\
MEL7 & 2.62 \\
MEL8 & 4.28 \\
MEL9 & 2.02 \\
MEL10 & 3.37 \\
\hline
\end{tabular}

The literature cited moisture content range was also considered appropriate for the present prepared meloxicam suspension lyophilisates. Analysing our final MEL products using the TGA method we have noticed that the loss in weight was between $40^{\circ} \mathrm{C}$ and $120^{\circ} \mathrm{C}$, which corresponds to the loss of the bound water. Also, using the TGA software we determined the moisture content of the ten MEL products (Table III). In the condition of a secondary drying stage at $10^{\circ} \mathrm{C}$ and 0.2 mbar for 6 hours the moisture content fell within the established range for MEL products 7 and 9 .

\section{Morphology}

The most representative SEM micrographs of the obtained MEL oral lyophilisates with medium content of the matrix forming agents are presented in Figures 7(a), 7(b) and 7(c). The obtained oral lyophilisates had porous structures, which indicated an appropriate lyophilization cycle. That is sustained by the fact that there are no signs of collapse or melt-back in the cakes. MEL modifies partially its physical properties during the process and that is confirmed in the SEM micrographs by the visible presence of MEL crystals in the structure of the oral lyophilisates. Thus, the CCS oral lyophilisate, MEL2 (Figure 7(a)), presented porous but irregular structures containing areas with variable densities and walls with a discontinuous aspect, in which CCS appears rather agglomerated, which gives them very poor mechanical properties. The structure of the SA oral lyophilisate, MEL7 (Figure 7(b)), is an aired one but with small pores which give the cake a higher density and better mechanical strength [19]. The MEL crystals were visible in the pore walls. On the other side, GEL oral lyophilisate, MEL10 (Figure 7(c)), showed aired structures with large pores and regular shapes, which grant fast disintegration and also visible MEL crystals in the walls. 
FARMACIA, 2019, Vol. 67, 1

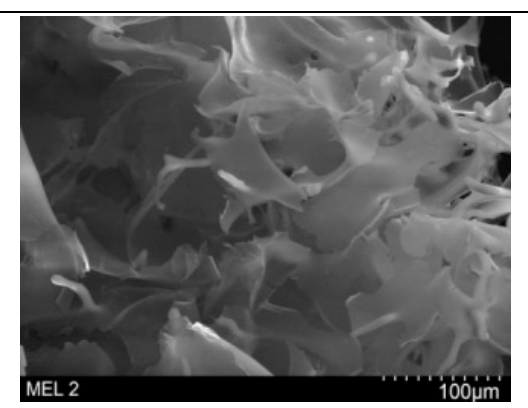

(a)

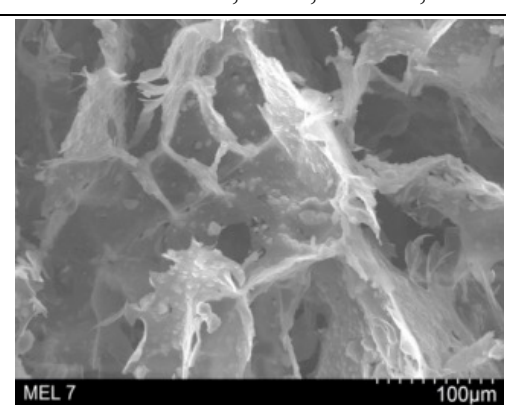

(b)

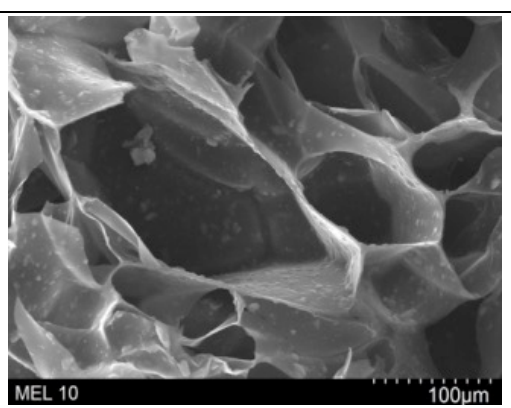

(c)

Figure 7.

Representative SEM micrographs of meloxicam oral lyophilisates: (a) MEL2; (b) MEL7; (c) MEL10 MEL2, MEL7, MEL10, meloxicam oral lyophilisates 2, 7, 10

\section{Conclusions}

In all stages of our study, we applied DSC in a sciencebased manner, in order to guide the development process of meloxicam oral lyophilisates. Following the DSC, FTIR and XRPD results in the pre-formulation stage we could conclude that the chosen excipients were compatible with the API. They were included in a study protocol for oral lyophilisates preparation. In this stage the critical temperatures: glass transition Tg', and melting were determined by DSC which oriented the primary drying parameters establishment with the inclusion of an annealing step. The chosen freeze drying cycle lead to oral lyophilisates that were again characterized by DSC and TGA for the assessment of their crystallinity and moisture content. The results revealed a partial loss of crystallinity confirmed by XRPD and moisture content within or close to the recommended limits. Finally, the morphology of the obtained MEL oral lyophilisates was determined by SEM, which indicated that they present porous structures, sign of an appropriate lyophilization cycle.

This study sustains the use of thermal methods, and especially DSC throughout freeze dried products development and process design. Moreover, thermal methods are fast, cheap and widely available, which recommends their use both in the academic research field and by the companies that produce freezedried products.

\section{Acknowledgement}

This research was funded by "Iuliu Haţieganu" University of Medicine and Pharmacy, Cluj-Napoca, Romania, grant number 4944/13/08.03.2016.

\section{References}

1. $* * *$ European Pharmacopoeia, 8.2 edition [Internet]. The Directorate for the Quality of Medicines of the Council of Europe (EDQM), Strasbourg, France. 2014. http://online6.edqm.eu/ep802/.

2. Abd Elbary A, Ali AA, Aboud HM, Enhanced dissolution of meloxicam from orodispersible tablets prepared by different methods. Bull Fac Pharm. Cairo Univ., 2012; 50(2): 89-97.

3. AlHusban F, Perrie Y, Mohammed AR, Formulation and characterisation of lyophilised rapid disintegrating tablets using amino acids as matrix forming agents. Eur J Pharm Biopharm., 2010; 75(2): 254-262.

4. Alhusban F, Perrie Y, Mohammed AR, Formulation of multiparticulate systems as lyophilised orally disintegrating tablets. Eur J Pharm Biopharm., 2011; 79(3): 627-634.

5. Araújo AAS, Bezerra MS, Storpirtis S, Matos JR, Determination of the melting temperature, heat of fusion, and purity analysis of different samples of zidovudine (AZT) using DSC. Braz J Pharm Sci., 2010; 46: 37-43.

6. Araujo AAS, Storpirtis S, Mercuri L, Carvalho FMS, Filho dos Santos M, Matos JR, Thermal analysis of the antiretroviral zidovudine (AZT) and evaluation of the compatibility with excipients used in solid dosage form. Int J Pharm., 2003; 260(2): 303-314.

7. Ayensu I, Mitchell JC, Boateng JS, Development and physico-mechanical characterisation of lyophilised chitosan wafers as potential protein drug delivery systems via the buccal mucosa. Colloids Surf B Biointerfaces, 2012; 91: 258-265.

8. Baird JA, Taylor LS, Evaluation of amorphous solid dispersion properties using thermal analysis techniques. Adv Drug Deliv Rev., 2012; 64(5): 396-421.

9. Bartos C, Ambrus R, Sipos P, Budai-Szücs M, Csányi E, Gáspár R, Márki Á, Seres AB, Sztojkov-Ivanov A, Horváth T, Szabó-Révész P, Study of sodium hyaluronate-based intranasal formulations containing micro- or nanosized meloxicam particles. Int J Pharm., 2015; 491(1): 198-207.

10. Chadha R, Bhandari S, Drug-excipient compatibility screening - Role of thermoanalytical and spectroscopic techniques. J Pharm Biomed Anal., 2014; 87: 82-97.

11. Chandrasekhar R, Hassan Z, Alhusban F, Smith AM, Mohammed AR, The role of formulation excipients in the development of lyophilised fast-disintegrating tablets. Eur J Pharm Biopharm., 2009; 72(1): 119-129.

12. da Silveira LM, Fiorot AB, Xavier TP, Yoshida MI, de Oliveira MA, Drug-excipient compatibility assessment of solid formulations containing meloxicam. Eur $J$ Pharm Sci., 2018; 112: 146-151.

13. de Oliveira AM, Yoshida IM, Silva CD, Quality Evaluation of Pharmaceutical Formulations Containing 
FARMACIA, 2019, Vol. 67, 1

Hydrochlorothiazide. Molecules, 2014; 19(10): 1682416836.

14. Dias RJ, Ranjan S, Mali KK, Ghorpade VS, Havaldar VD, Liquisolid compacts of meloxicam: in-vitro and in-vivo evaluation. Egypt Pharm J., 2017; 16(2): 112-120.

15. ElShaer A, Hanson $\mathrm{P}$, Worthington T, Lambert $\mathrm{P}$, Mohammed AR, Preparation and characterization of amino acids - based trimethoprim salts. Pharmaceutics, 2012; 4(1): 179-196

16. Harnkarnsujarit $\mathrm{N}$, Charoenrein $\mathrm{S}$, Roos $\mathrm{YH}$, Microstructure formation of maltodextrin and sugar matrices in freeze-dried systems. Carbohydr Polym., 2012; 88(2): 734-742.

17. Hegheș SC, Rus LM, Rus LL, Bojiță MT, Iuga AC, HPLC-UV determination of indapamide in the presence of its main synthesis and degradation impurities. Method validation. Farmacia, 2017; 65(5): 755-760.

18. Issa AA, Marchidan D, Cojocaru V, Anuța V, Preparation and evaluation of meloxicam solid dispersion by melting method. Farmacia, 2013; 61(6): 1216-1232.

19. Iurian S, Bogdan C, Tomuta I, Szabo-Revesz P, Chvatal A, Leucuta SE, Moldovan M, Ambrus R, Development of oral lyophilisates containing meloxicam nanocrystals using QbD approach. Eur J Pharm Sci., 2017; 104: 356-365.

20. Iurian S, Tomuta I, Bogdan C, Rus L, Tokes T, BarbuTudoran L, Achim M, Moldovan M, Leucuta S, Defining the design space for freeze-dried orodispersible tablets with meloxicam. Drug Dev Ind Pharm., 2016; 42(12): 1977-1989.

21. Kasper JC, Winter G, Friess W, Recent advances and further challenges in lyophilization. Eur J Pharm Biopharm., 2013; 85(2): 162-169.

22. Kiss D, Zelko R, Novak C, Ehen Z, Application of DSC and NIRS to study the compatibility of metronidazole with different pharmaceutical excipients. $J$ Therm Anal Calorim., 2006; 84(2): 447-451.

23. Kürti L, Kukovecz Á, Kozma G, Ambrus R, Deli MA, Szabó-Révész P, Study of the parameters influencing the co-grinding process for the production of meloxicam nanoparticles. Powder Technol., 2011; 212(1): 210-217.

24. Lai F, Pini E, Corrias F, Perricci J, Manconi M, Fadda AM, Sinico C, Formulation strategy and evaluation of nanocrystal piroxicam orally disintegrating tablets manufacturing by freeze-drying. Int J Pharm., 2014; 467(1): 27-33.

25. Mata JP, Majhi PR, Guo C, Liu HZ, Bahadur P, Concentration, temperature, and salt-induced micellization of a triblock copolymer Pluronic L64 in aqueous media. $J$ Colloid Interface Sci., 2005; 292(2): 548-556.

26. Maunab P, Prajit KA, Saurabh S, Meenakshi S, editors. Differential Scanning Calorimetry (DSC) an essential and critical instrument in optimizing lyophilization process. Int J Life Sci Pharma Res., 2013 Oct-Dec.

27. Mesnukul A, Yodkhum K, Phaechamud T, Solid dispersion matrix tablet comprising IndomethacinPEG-HPMC fabricated with fusion and mold technique. Ind J Pharmaceut Sci., 2009; 71(4): 413420 .
28. Mohamed AI, Abd-Motagaly AME, Ahmed OAA, Amin S, Mohamed Ali AI, Investigation of drugpolymer compatibility using chemometric-assisted UV-Spectrophotometry. Pharmaceutics, 2017; 9(1): 7: 1-13.

29. Moisei A, Gligor F, Bojiţă M, Chiş A, Totan M, Vonica-Gligor LA, Ciurba A, Compatibility and stability studies of antihypertensive/excipients by thermal methods, used in the preformulation phase. Farmacia, 2014; 62(6): 1239-1248.

30. Mukherjee I, Rosolen M, Thermal transitions of gelatin evaluated using DSC sample pans of various seal integrities. $J$ Therm Anal Calorim., 2013; 114 : 1161-1166.

31. Mura P, Faucci MT, Manderioli A, Bramanti G, Ceccarelli L, Compatibility study between ibuproxam and pharmaceutical excipients using differential scanning calorimetry, hot-stage microscopy and scanning electron microscopy. J Pharm Biomed Anal., 1998; 18: 151-163.

32. Pandit $\mathrm{V}$, Pai RS, Devi $\mathrm{K}$, Suresh $\mathrm{S}$, In vitro-in vivo evaluation of fast-dissolving tablets containing solid dispersion of pioglitazone hydrochloride. $J$ Adv Pharmaceut Tech Res., 2012; 3(3): 160-170.

33. Pathak D, Dahiya S, Pathak K, Solid dispersion of meloxicam: factorially designed dosage form for geriatric population. Acta Pharm., 2008; 58(1): 99-110.

34. Pomázi A, Buttini F, Ambrus R, Colombo P, SzabóRévész $\mathrm{P}$, Effect of polymers for aerolization properties of mannitol-based microcomposites containing meloxicam. Eur Polym J., 2013; 49(9): 2518-2527.

35. Rey L, May JC, editors. Freeze-Drying/Lyophilization of Pharmaceutical and Biological Products. $3^{\text {rd }}$ ed. London: Informa healthcare, 2010.

36. Rowe RC, Sheskey PJ, Cook WG, Fenton ME, Handbook of pharmaceutical excipients $-7^{\text {th }}$ edition, 2009.

37. Rus LM, Tomuţa I, Iuga C, Maier C, Kacso I, Borodi G, Bratu I, Bojiţă M, Compatibility studies of indapamide/pharmaceutical excipients used in tablet preformulation. Farmacia, 2012; 60(1): 92-101.

38. Saleh A, McGarry K, Chaw SC, Elkordy AA, Feasibility of using gluconolactone, trehalose and hydroxy-propyl gamma cyclodextrin to enhance bendroflumethiazide dissolution using lyophilisation and physical mixing techniques. Pharmaceutics, 2018; 10(1): 22: 1-16.

39. Sarfraz RM, Ahmad M, Mahmood A, Khan HU, Bashir S, Minhas MU, Sher M, Comparative Study of Various Polymeric Superdisintegrants on the Design and Evaluation of Novel Antihypertensive Orodispersible Tablets. Adv Polym Tech., 2016; 35(4): 378-385.

40. Shende PK, Gaud RS, Bakal R, Patil D, Effect of inclusion complexation of meloxicam with betacyclodextrin- and beta-cyclodextrin-based nanosponges on solubility, in vitro release and stability studies. Colloids Surf B Biointerfaces, 2015; 136: 105-110.

41. Sirisolla J, Solubility enhancement of meloxicam by liquisolid technique and its characterisation. Int J Pharm Sci Res., 2015; 6(2): 835-840.

42. Soares JP, Santos JE, Chierice GO, Cavalheiro ETG, Thermal behavior of alginic acid and its sodium salt. Eclética Química, 2004; 29(2): 57-64. 
43. Stulzer HK, Rodrigues PO, Cardoso TM, Matos JSR, Silva MAS, Compatibility studies between captopril and pharmaceutical excipients used in tablets formulations. J Therm Anal Calorim., 2008; 91(1): 323-328.

44. Sundaramurthi P, Suryanarayanan R, Calorimetry and complementary techniques to characterize frozen and freeze-dried systems. Adv Drug Deliv Rev., 2012; 64(5): 384-395.

45. Tita D, Jurca T, Fulias A, Marian E, Tita B, Compatibility study of the acetylsalicylic acid with different solid dosage forms excipients. $J$ Therm Anal Calorim., 2013; 112(1): 407-419.

46. Verma RK, Garg S, Compatibility studies between isosorbide mononitrate and selected excipients used in the development of extended release formulations. J Pharm Biomed Anal., 2004; 35(3): 449-458.
47. Vicini S, Castellano M, Mauri M, Marsano E, Gelling process for sodium alginate: New technical approach by using calcium rich micro-spheres. Carbohydr Polym., 2015; 134: 767-774.

48. Wang Y, Zheng Y, Zhang L, Wang Q, Zhang D, Stability of nanosuspensions in drug delivery. $J$ Control Release, 2013; 172(3): 1126-1141.

49. Xie Y, Li G, Yuan X, Cai Z, Rong R, Preparation and in vitro evaluation of solid dispersions of total flavones of Hippophae rhamnoides L. AAPS Pharm Sci Tech., 2009; 10(2): 631-640.

50. Yener G, Üner M, Gönüllü Ü, Yildirim S, Kiliç P, Aslan SS, Barla A, Design of meloxicam and lornoxicam transdermal patches: Preparation, physical characterization, ex vivo and in vivo studies. Chem Pharm Bull., 2010; 58(11): 1466-1473. 